\title{
THE ROLE OF EMPLOYMENT MOTIVATION TO MEDIATE THE INFLUENCE OF NON-PHYSICAL WORK ENVIRONMENT AND COMMUNICATIONS ON MORALE OF WORKERS WITH DISABILITY IN REGENCY/CITY GOVERNMENT AGENCIES IN BALI, INDONESIA
}

\author{
Darmawan Gede Widya*, Surya Ida Bagus Ketut \\ Faculty of Economics and Business, University of Udayana, Bali, Indonesia \\ *E-mail: gedecikde@gmail.com
}

\begin{abstract}
Employing workers with disabilities is a mandate contained in the law. The mandate also provides rights and obligations for persons with disabilities to be able to carry out their lives, including getting decent work without discrimination. Disability workforce is one of the diversity that must be managed properly in an agency in order to help achieve organizational goals, in particular, in Regency/City Local Government Agencies. In this literature, it is becoming increasingly important to understand the factors that influence morale. This study aims to explain the role of work motivation as a mediator of the influence of the non-physical work environment and communication on the morale of workers with disabilities in Regency / City Government Agencies throughout Bali. Respondents from this study were 33 people, using a saturated/census sampling technique, namely all workers with special disabilities in Regency/City Government Agencies throughout Bali. Data was collected through unstructured interviews and using a questionnaire. Data were analyzed using Structural Equation Model (SEM) using PLS (Partial Least Square) analysis technique. The results of this study indicate that the non-physical work environment, communication and work motivation have a positive and significant effect on morale. Non-physical work environment and communication have a positive and significant effect on work motivation. Work motivation partially mediates the influence of the non-physical work environment on morale and the influence of communication on morale.
\end{abstract}

\section{KEY WORDS}

Morale, non-physical work environment, communication, work motivation.

In general, companies have clear goals in developing their business. The company is an association of two or more people who have the same principles and interact with each other in carrying out their activities to achieve common goals. Success in managing the company cannot be separated from the intervention of human resources because human resources are the main capital owned by a company to achieve a goal effectively and efficiently, thus it can be said that this is closely related to human resource management.

Human resource management is a process, utilizing human resources effectively and efficiently through planning, mobilizing, and controlling all values that become human strength to achieve goals (Sedarmayanti, 2017: 3). Human resource management aims to improve the productive contribution of people to the organization in a strategically, ethically and socially responsible manner. The purpose of human resource management in general is to ensure that the organization is able to achieve success through the cooperation and active contribution of humans (Wibowo, 2017:7).

An organization is essentially a group of people who collaborate to accomplish defined objectives. The accomplishment of organizational objectives is inextricably linked to the activities of its members. They can work well if they are based on morale (Rasdam, Syamsu. et al, 2018). Pattnaik and Jena (2020) give the results that morale is a state of mind that reflects enthusiasm, spirit, satisfaction, and overall attitude in one's work. Morale is said to be a productivity driver, because satisfied employees tend to be high performers. When employee morale is high, the organization reaches its full potential in terms of business and profitability. 
Morale is often associated with the attitude or behavior of employees towards the work they do by paying attention and observing the attitudes and behavior of employees towards their work, which can then be known to what extent the employee has worked productively, where high productivity can be achieved by employees who have high morale (Murtisaputra and Sri, 2018). Paramina and Heni (2018) state that morale really needs to be improved, because it is a supporting element in achieving the goals desired by the company. High morale will stimulate employees to work and do better activities. Yani, et al (2020) give the result that morale is a condition that must exist if work process activities want to run smoothly. High morale will make employees work with feelings of pleasure so that they will be able to excel in their work. Morale has a significant impact or influence for employees and for the company which will later help achieve the goals of a company

The work environment is also an aspect that must be considered by the company because it will foster employee morale (Yahyo, et al. 2013). Sedarmayanti (2017: 21) provides a definition that the non-physical work environment is all conditions that occur related to work relationships, both relationships with superiors and relationships with fellow co-workers, or relationships with subordinates. Non-physical work environment, namely a pleasant work environment in the sense of creating a harmonious working relationship between employees and superiors, because essentially humans at work are a form of activity that aims to get satisfaction (Sari, et al. 2015). Similar to this opinion, it can be concluded that the non-physical work environment is all conditions that occur related to working relationships both with superiors and with colleagues or with subordinates that need to be created to create a work atmosphere that can make the workforce eager to work harder and better.

Research conducted by Chandra and Setiawan (2018) shows that the non-physical work environment has a positive and significant influence on morale. These results are in line with research conducted by Sinamora (2018); Darmawan and Wibawa (2019); Tambunan (2018) which gives the result that the non-physical work environment has a positive and significant effect on morale, both partially and simultaneously. This means that a good nonphysical work environment will provide personal comfort and can raise employee morale so that they can do their jobs well.

Different research results were found by Rozi (2021) which gave the result that the work environment variable did not have a significant effect on morale for the company he studied, namely PT Jaya Anugrah Sukses Abadi Supermarket in Brastagi, Medan. The results of this study are also in line with the research conducted by Manihuruk and Tirtayasa (2020) which partially obtained the results that the work environment had an insignificant effect on morale, while simultaneously the variables of work stress, work motivation and work environment had a significant influence on morale employee at the Department of Population and Civil Registration of North Labuhanbatu.

Another factor that affects the morale of the workforce is communication (Pratiwi and Netra, 2020). Communication is the key to open a cooperative relationship between the leader and the workforce and between the workers themselves (Ardana, et al. 2012:138). McShane and Glinow (2008) in Supartha and Sintaasih (2017:79) provide a definition that communication is the delivery or exchange of information from the sender to the recipient either orally, in writing or using communication tools. Research by Widani (2018) gives the results that communication has a significant effect on employee morale, this means that good communication between leaders and employees and good communication between employees and employees will affect employee morale. The results of the research by Wijaya and Hamid (2015) found that communication, both formal and informal, had a direct effect on the morale of the employees of PT. Sumber Cipta Multiniaga Pasuruan, so to increase employee morale, it can be done by improving the quality of formal and informal communication within the company. Supporting these results, Diana and Subudi (2013) conclude that communication affects employee morale at Auto 2000 Tabanan, with a value of 32.1 percent, which means that 32.1 percent of employee morale is influenced by communication. 
The most important benefit of motivation is to create work passion / enthusiasm for work (Meira, 2020). Sedarmayanti (2017:15) states that work motivation is something that gives rise to encouragement or enthusiasm for work. Supartha and Sintaasih (2017: 27) provide a definition that motivation is a condition in a person's personality that encourages the desire to carry out certain activities in order to achieve a goal. The motivation that exists in a person, will realize a behavior that is directed at the goal of achieving the target of satisfaction. Every activity carried out by a person is driven by a force from within that person; This driving force is called motivation.

The results of research conducted by Sari (2020) found that motivation had a positive effect on employee morale at the Palembang Financial Education and Training Center office, linear results were also found by Supriyanti, et al (2020) which stated that there was a partial and simultaneous significant effect between motivation on the morale of employees at Teluk Singkawang Health Center, Sumay District, Tebo Regency. Research by Yahyo, et al (2013); Sudiran and Salasiah (2019); Utamajaya and Sriathi (2015) who both gave the result that the work motivation variable had a significant effect on employee morale. Paramina and Sari (2017) get different results, the results of their research conclude that the work motivation variable has no positive and significant effect on employee morale from PT. Carefast Semarang.

The emergence of a research question posed by Robbins and Judge (2017: 59) is "How can we take advantage of differences in groups for competitive advantage? Should we treat the workforce the same? It is the beginning to start discussing further about this disabled workforce. Disability workforce is one of the diversity that must be managed properly in an organization in order to help achieve the goals of the organization. Robbins and Judge (2017:59) state that one of the most important challenges for organizations is managing workforce diversity, a trend for organizations to become more heterogeneous in terms of differences in other characteristics such as a workforce with disabilities, managing this diversity has become a concern as well as a challenge in any organization.

Every individual certainly has a religion, but often the leaders of companies or organizations sometimes forget that they need to recognize and take advantage of individual differences or diversity to get the most out of their workforce. Law Number 8 of 2016 concerning Persons with Disabilities provides a definition of persons with disabilities as stated in Chapter I General Provisions Article 1 number 1 which states that persons with disabilities are any person who has limitations in terms of physical, intellectual, mental, and/or sensory a long period of time in interaction with the environment may experience obstacles or difficulties to participate fully and effectively with other citizens based on equal rights. Persons with disabilities experienced by each person are determined from two factors, namely internal and external factors. The internal factor of a person experiencing a disability is because he has found a physical deficiency (disability) since birth, in terms of heredity or in terms of disability due to other things while still in the womb while disability from external factors is a natural disaster, work accident, or the presence of an illness thereby endangering the person if no medical action is taken. The workforce is everyone who is able to work, both inside and outside the employment relationship in order to produce goods or services to meet the needs of the community, in this case, disabled workers are also human resources that must be managed properly, so that later they can assist in achieving goals from a company that is shaded by their limitations.

Each Regional/Regency Government Institution in the Province of Bali has a special workforce for persons with disabilities, even though it has not been able to meet the minimum quota mandated in the Act. As regulated in Article 53 of Law No. 8 of 2016 in paragraph (1) which states that the Government, Regional Governments, State-Owned Enterprises, and Regional-Owned Enterprises are required to employ at least $2 \%$ (two percent) of persons with disabilities of the total number of employees or workers, as well as in paragraph (2) which states that "private companies are required to employ at least $1 \%$ (one percent) of persons with disabilities from the total number of employees or workers. The distribution of disabled workers employed in each Regency/City Government Agency in Bali can be described as following: 
Table 1 - Distribution of Workers with Disabilities

\begin{tabular}{ccc}
\hline No & Regency/City & Number of Workers with Disabilities (Persons) \\
\hline 1 & Denpasar & 24 \\
\hline 2 & Badung & 3 \\
\hline 3 & Gianyar & 2 \\
\hline 4 & Karangasem & 0 \\
\hline 5 & Bangli & 2 \\
\hline 6 & Jembrana & 3 \\
\hline 7 & Tabanan & 4 \\
\hline 8 & Buleleng & 5 \\
\hline 9 & Klungkung & 2 \\
\hline & Total & 45 \\
\hline
\end{tabular}

Source: Various Online Media Resources and BKPSDM Websites throughout Regency/City Local Government Agencies in Bali (2020).

Table 1 shows that almost all Regency/Municipal Government Agencies in Bali Province already have disabled workers. The presence of this disabled workforce must of course be a special concern for agency leaders in managing the workforce, so that they can work well and in accordance with their abilities and limitations. The results of an unstructured initial interview with one person with a disability who works as an honorary worker in an office located in Denpasar City, there is a phenomenon that illustrates that many people with disabilities who work have low morale.

The low morale of disabled workers can be seen from the presence of some workers who look lazy at work. The emergence of this feeling of laziness is caused because the tasks received are often changing and uncertain. Furthermore, there is a feeling of restlessness at work. This anxiety often occurs because there are several colleagues from the general line (non-disabled) who often compare the work and compensation received by workers with disabilities, triggering disputes between workers, as well as negative stereotypes (negative perceptions) by non-disabled workers. This makes disabled workers feel annoyed, sad, and disappointed with their fellow co-workers, which if this is ignored and happens continuously, it will have an impact on decreasing the morale of the disabled workforce.

The differences in the results of the research that have been described in the background of the problem and the limited research on disabled workers associated with the non-physical work environment, communication, work motivation and morale, this study will analyze the role of work motivation in mediating the influence of the non-physical work environment, and communication on the morale of disabled workers in Regency/City Local Government Agencies throughout Bali.

\section{LITERATURE REVIEW AND HYPOTHESES DEVELOPMENT}

Non-physical work environment, i.e. pleasant work environment in the sense of fostering a happy working relationship between employees and superiors, because work is primarily a form of activity aimed at obtaining fulfillment (Sari, et al. 2015). Research conducted by Darmawan and Wibawa (2019) provides the results that the non-physical work environment partially and simultaneously has a significant effect on employee morale. In line with this research, Sari (2015) obtained the results that there was a significant positive effect between the non-physical work environment on work morale. Minor K. I. (2014) stated that one of the factors that affect work morale is the work environment. Chandra and Setiawan (2018) explain that the work environment, both physical and non-physical, has a significant effect on employee morale. An open and honest work environment between leaders and employees will be able to increase employee morale (Sharma, P. 2021). Devi and Kannadhajan (2020) state that the work environment is an important factor in increasing or decreasing morale. The work environment determines the increase or decrease in morale (Sabitova et.al, 2020).

Based on the theoretical basis and the research results that have been described, the following hypotheses are put forward: 
H1: Non-Physical Work Environment Has a Positive and Significant Effect on Morale.

Communication is an understanding of something that is not visible and hidden, this hidden and symbolic element is inherent in culture that gives meaning to the communication process that can be seen or communication is a personal process that includes behavior change (Luthans, 2006:372). Pattnaik and Jena (2020) state that effective communication helps trust between an employee and superiors/coworkers/subordinates. Communication has a positive effect on morale, this is due to the feeling of happiness that grows from the communication that exists (Singh and Shastri, 2020). Drake (2021) gives the result that communication is one of the important components to increase employee morale. Research by Widani (2018) also gives results that communication has a significant effect on employee morale. The existence of effective communication such as listening and respecting every opinion, will affect employee morale (Sharma, P. 2021). Based on the theoretical basis and the research results that have been described, the following hypotheses are put forward:

H2: Communication Has a Positive and Significant Effect on Morale.

Employees will be motivated to provide good work results if they receive adequate rewards such as bonuses, awards, extra leave and so on (Supartha and Sintaasih, 2017:26). Research conducted by Rozi (2021) explains that the motivation variable has a positive and significant effect on work morale. Ali et. al (2020) stated that paying attention to employee work motivation in particular, will affect the morale of the employee. Motivation is an important factor that can increase employee morale (Nur et. al, 2021). Sari (2020) obtained research results that motivation has a positive effect on employee morale, research with linear results was also found by Iswara and Subudi (2017) where the motivation variable has a positive and significant effect on employee morale, then Sudiran and Salasiah (2019) get the results of the study that there is a positive influence between work motivation on employee morale. Danaeefard and Abdolali (2020) give the result that in order to increase work morale, employees must be motivated. Employee work motivation is able to increase employee morale (Ali and Anwar, 2021). Based on the theoretical basis and the research results that have been described, the following hypotheses are put forward:

H3: Motivation has a positive and significant effect on morale.

Sedarmayanthi (2017: 31) states that the non-physical work environment is all conditions that occur related to working relationships both with superiors and relationships with fellow co-workers or relationships with subordinates. Harmonious results are also shown by Chandra and Viantia (2020) that the physical and non-physical work environment has a positive and significant influence on work motivation and job satisfaction. This research is also in line with Sinamora, et al (2016) which gives the results that non-physical work environment variables have a significant simultaneous effect on employee work motivation. Alisa, et al (2016) also concluded that the work environment, both physical and non-physical, simultaneously and partially affects employee work motivation. It is important in increasing work motivation, paying attention to the work environment of employees (Kjellstrom et. al, 2017). Referring to the results of previous studies, it can be concluded that the better the non-physical work environment in an agency, the higher the work motivation of its workforce. Based on the theoretical basis and the results of the research that have been described, the following hypothesis is put forward:

H4: Non-Physical Work Environment Has a Positive and Significant Effect on Work motivation.

Robbins and Judge (2017:383) state that communication must include the transfer and understanding of meaning. Lee et. al (2020) stated that the existence of transparent communication, it will increase the motivation of the employee. Mahmoud et. al (2021) stated that the importance of communication in building work motivation. Wilson (2020) states that it is important for leaders to maintain methods of building communication that have an impact on increasing motivation. Pekkala (2020) states that communication is considered important in building employee motivation. Gautam and Basnet (2020) give the result that communication has a positive influence on work motivation. Based on the theoretical basis and the research results that have been described, the following hypotheses are put forward:

H5: Communication Has a Positive and Significant Effect on Work Motivation. 
Research conducted by Arifin and Wulandari (2021) states that the work environment, both physical and non-physical, has a partial effect on the morale of the education staff at SMK Krian 2 Sidoarjo. Pratiwi (2021) concludes that there is an influence of motivation on work morale, either partially or simultaneously at the Purbalingga City Regional Secretariat Office. Kundu and Kusum (2017) state that the work environment has an important role in increasing employee motivation in preventing employee turnover. It is important in increasing work motivation, paying attention to the work environment of employees (Kjellstrom et. al, 2017). Ali et. al (2020) stated that paying attention to employee work motivation in particular, will affect the morale of the employee. Therefore, companies need to know in advance what things can motivate and encourage employee morale. Referring to the results of previous studies, it can be concluded that work motivation can be a mediating variable, because it has a direct and indirect influence on the work spirit variable. The better the non-physical work environment in an agency, the employee's work motivation will increase so that it will affect the morale of the workforce. Based on the theoretical basis and the research results that have been described, the following hypotheses are put forward: Morale.

H6: Work Motivation Mediates the Effect of Non-Physical Work Environments on

Communication will allow each member of the organization to help each other and interact with each other (Sinamora and Panjaitan, 2017). Lee et. al (2020) stated that the existence of transparent communication, it will increase the motivation of the employee. Mahmoud et. al (2021) stated that the importance of communication in building work motivation. Therefore, in terms of one's communication, accuracy, skill and caution are needed so that the motivation formed is in accordance with the expected goals. Danaeefard and Abdolali (2020) give the result that in order to increase work morale, employees must be motivated. Employee work motivation is able to increase employee morale (Ali and Anwar, 2021), this means that the stronger the work motivation, the employee's morale will increase. So that employees and employees can continue to work well and provide the best performance for the company or organization, the employees and employees need to be motivated. Referring to the results of previous studies, it can be concluded that work motivation has a direct and indirect influence on the morale variable, which means that the better the communication that exists within an agency, the employee's work motivation will increase so that it will affect the morale of the workforce. Based on the theoretical basis and the research results that have been described, the following hypotheses are put forward:

H7: Work Motivation Mediates the Effect of Communication on Morale.

\section{METHODS OF RESEARCH}

This study uses the type of quantitative data analyzed associative. Data collection techniques through direct interviews with respondents with a list of unstructured questions used to obtain information related to the object of research. The interviews also required a deaf interpreter, as a facilitator to facilitate the delivery of messages to disabled workers, especially the deaf. In addition, data collection is also carried out through the distribution of questionnaires to employees/labor specifically for persons with disabilities, both those who have the status of Civil Servants (PNS) or temporary workers employed at every Regency/City Government Agency in Bali. The location of this research was taken because there were problems related to the morale of the workforce according to the results of unstructured interviews. The time of this research was carried out during March 2021 to the end of August 2021 which included planning research variables, distributing questionnaires, discussing research, and producing conclusions and research suggestions. The total population in this study was 45 people, so this study used the saturated sample or census method in which 45 workers were used as respondents. The data analysis method used was descriptive statistical analysis and inferential statistical analysis which were analyzed with Smart-PLS software. 


\section{RESULTS AND DISCUSSION}

Questionnaires have been distributed to the entire population in this study, as many as 45 people. The returned questionnaires were 33 questionnaires, while the remaining 12 questionnaires were not collected by the researcher because 11 respondents were not willing to become respondents and 1 respondent experienced prolonged illness. So the research will use 33 respondents with a response rate of 73.3 percent. The results of the characteristics of the respondents in this study showed that there were 26 male respondents with a percentage of 78.8 percent and 7 women with a percentage of 21.2 percent. The types of disability that are carried by respondents consist of 4 people with mental disabilities with a percentage of 12.1 percent, 22 people with sensory disabilities with a percentage of 66.7 percent, and physical disabilities with a percentage of 7 people with a percentage of 21.2 percent. The age of the respondents in this study who was younger than 20 years was 1 person with a percentage of 3 percent, the age range of 21-30 years was 18 people with a percentage of 54.5 percent, the age range of 31-40 years was 9 people with a percentage of 27.3 percent and the age range of $41-50$ years as many as 5 people with a percentage of 15.2 percent. The characteristics of the agencies where respondents work are spread out in Denpasar City Government Agencies as many as 20 people with a percentage of 60.6 percent, Badung Regency Government Agencies as many as 2 people with a percentage of 6.1 percent, Tabanan Regency Government Agencies as many as 4 people with a percentage of 12, 1 percent, Jembrana Regency Government Agencies as many as 2 people with a percentage of 6.1 percent, Buleleng Regency Government Agencies 3 people with a percentage of 9 percent, and Klungkung Regency Government Agencies as many as 2 people with a percentage of 6.1 percent. The position in the respondent's job is dominated by the staff position as many as 32 people with a percentage of 97 percent and the remaining 1 person occupies the position of the head of the field with a percentage of 3 percent. Furthermore, on the characteristics of the length of work, the majority of respondents were in the service period of less than 5 years as many as 28 people with a percentage of 84.8 percent and the remaining 5 people with a percentage of 15.2 percent were in the service period of 5-10 years.

Table 2 - Hypothesis Test Results

\begin{tabular}{|c|c|c|c|c|}
\hline $\mathrm{n} / \mathrm{n}$ & Path Coefficient & T Statistics & P Values & Description \\
\hline Non-physical work environment -> Morale & 0.306 & 2.463 & 0.014 & Accepeted \\
\hline Communication-> Morale & 0.428 & 4.666 & 0.000 & Accepeted \\
\hline Work motivation -> Morale & 0.333 & 3.196 & 0.001 & Accepeted \\
\hline Non-physical work environment -> Work motivation & 0.502 & 4.346 & 0.000 & Accepeted \\
\hline Communication -> Work motivation & 0.481 & 4.666 & 0.000 & Accepeted \\
\hline Non-physical work environment -> Work motivation -> Morale & 0.167 & 2.836 & 0.005 & Accepeted \\
\hline Communication -> Work motivation -> Morale & 0.160 & 2.258 & 0.024 & Accepeted \\
\hline
\end{tabular}

Source: Primary data processed, 2021.

Table 2 shows that the non-physical work environment has a positive and significant influence on work morale with a correlation coefficient value of 0.306 , $t$ statistics value of 2.463 and p-value of 0.014 or $<0.05$, then Hypothesis $1(\mathrm{H} 1)$ is accepted. This shows that the better the non-physical work environment, the higher the morale of workers with disabilities. Communication has a positive and significant influence on work morale with a correlation coefficient value of 0.428 , a t statistic value of 4.666 and a p-value of 0.000 or $<0.05$, then Hypothesis $2(\mathrm{H} 2)$ is accepted. This shows that the better the communication, the higher the morale of workers with disabilities. Work motivation has a positive and significant effect on work morale with a correlation coefficient value of 0.333 , a t statistic value of 3.196 and a pvalue of 0.001 or $<0.05$, then Hypothesis $3(\mathrm{H} 3)$ is accepted. This shows that the higher the work motivation possessed by the workforce, the higher the morale of workers with disabilities. The non-physical work environment has a positive and significant influence on work motivation with a correlation coefficient value of 0.502 , a t-statistics value of 4.346 and a p-value of 0.000 or $<0.05$, then Hypothesis $4(\mathrm{H} 4)$ is accepted. This shows that the better 
the non-physical work environment in a local government agency, the higher the work motivation of workers with disabilities.

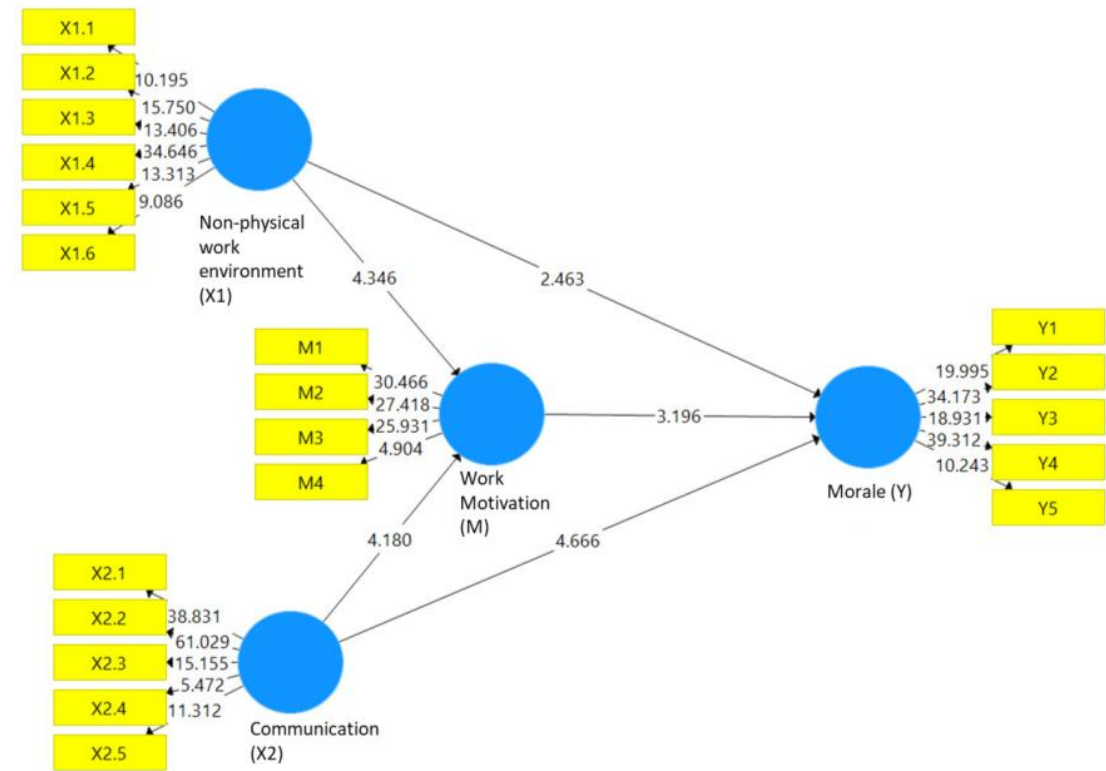

Figure 1 - Bootstrapping Results

Communication has a positive and significant influence on work motivation with a correlation coefficient of 0.481 , the value of t statistics of 4.666 and a p-value of 0.000 or $<0.05$, then Hypothesis $5(\mathrm{H} 5)$ is accepted. This shows that the better the communication, the higher the work motivation of workers with disabilities. Work motivation is able to mediate the influence of the non-physical work environment on morale, with a correlation coefficient value of 0.167 , a t statistic value of 2.836 and a p-value of 0.005 or $<0.05$, then Hypothesis 6 $(\mathrm{H} 6)$ is accepted, it shows that motivation work is able to mediate the influence of the nonphysical work environment on morale. Work motivation is able to mediate the effect of communication on morale, with a correlation coefficient value of 0.160 , a t-statistics value of 2.258 and a p-value of 0.024 or $<0.05$, then Hypothesis $7(\mathrm{H} 7)$ is accepted, it shows that work motivation is able to mediate the effect of communication on morale. Based on the data above, it can be concluded that the hypothesis in this study is entirely accepted.

This method of examining the mediation model follows the instructions of Hair et al. (2017), namely: regarding the mediating test of work motivation variable (M) on the influence of non-physical work environment $(\mathrm{X} 1)$ on work morale $(\mathrm{Y})$ and testing the mediation of work motivation variable $(\mathrm{M})$ on the effect of communication (X2) on work morale $(\mathrm{Y})$. ) which is depicted in Figures 2 and 3 as follows:

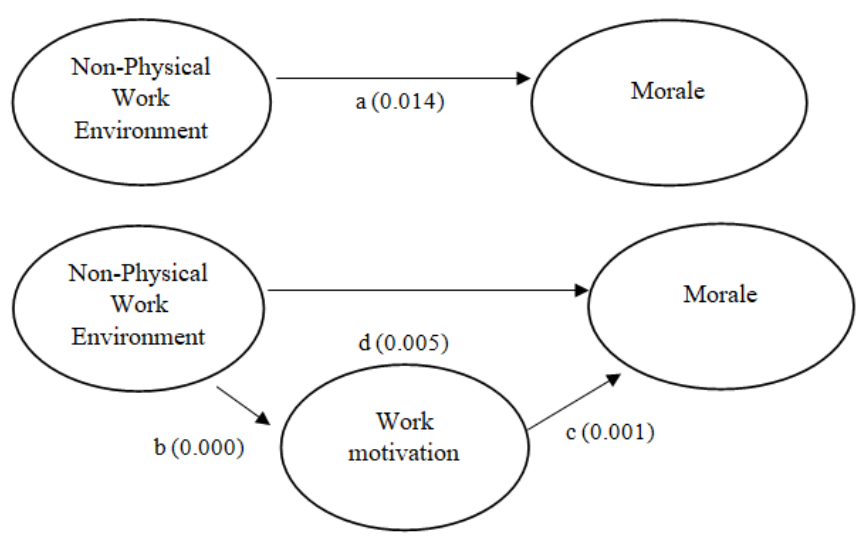

Figure 2 - Test Results of Direct and Indirect Effects of Non-Physical Work Environment, Work Motivation and Morale 


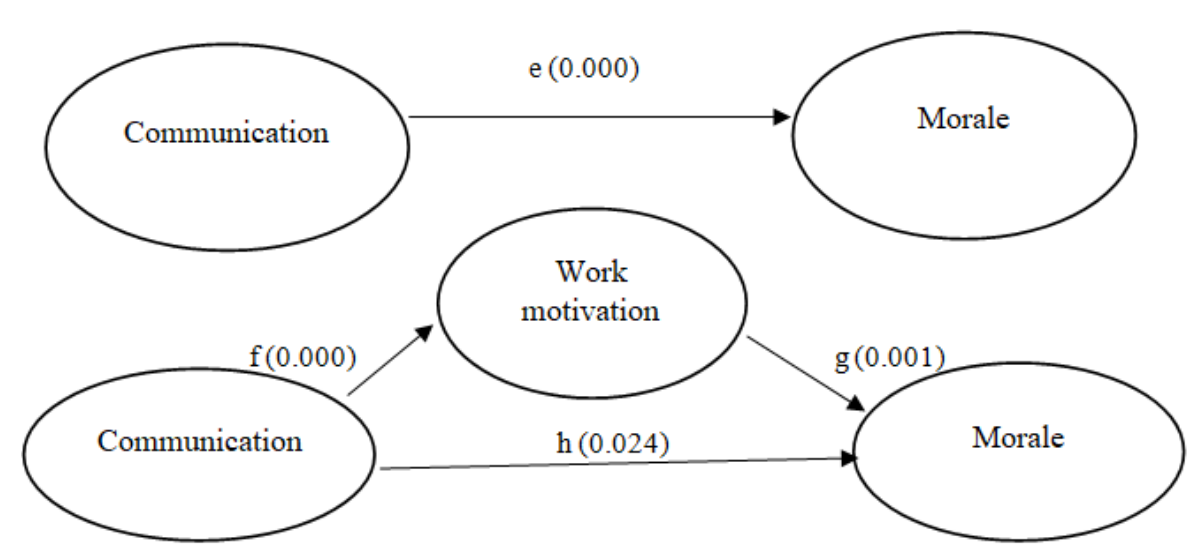

Figure 3 - Test Results Indirect Indirect Influence of Communication, Work Motivation and Morale

The mediation test was concluded through testing the direct and indirect effects between variables. Because the indirect effects (b), (c) and (f), (g) through the mediating variable of work motivation are significant, and the direct effects (a) and (e) are also significant, it can be concluded that work motivation (M) is proven as a partially mediated variable. This shows that work motivation is able to partially mediate the influence of the nonphysical work environment on morale and also work motivation is able to partially mediate the effect of communication on work morale.

1) Influence of Non-Physical Work Environment on Morale:

In the results of hypothesis testing, the non-physical work environment has a positive and significant effect on work morale. The results in this study are in line with the results of research conducted by Sari (2015) which obtained the results that there was a significant positive effect between the non-physical work environment on morale, the research conducted by Darmawan and Wibawa (2019) showed that the non-physical work environment was significantly partial and simultaneous significant effect on employee morale. And in line with the results of Chandra and Setiawan (2018); Tambunan (2018) which gives the result that the non-physical work environment has a positive and significant effect on work morale, both partially and simultaneously. This finding implies that the better the nonphysical work environment that occurs in Regency/City Local Government Agencies in Bali, the higher the morale of workers with disabilities.

The test results show that the focus of the higher morale due to the non-physical work environment include work procedures, work standards, responsibilities of the head of the field and relations between workers. For workers with disabilities, the existence of work procedures or a series of work implementation procedures that are arranged sequentially is considered important to be carried out by government agencies. Furthermore, regarding work standards, namely all task requirements, functions or behaviors set by government agencies that employ persons with disabilities. This work standard is considered important to be set in detail and clearly so that all workers with disabilities can understand and avoid mistakes.

Regarding the responsibility of the head of the field, namely the responsibility of a head of field or head of an agency in compiling the tasks of workers with disabilities so that they can be carried out effectively and fairly by looking at the degree of disability they carry which is then always monitored and evaluated to ensure the achievement of the targets set. The responsibility of the head of field in a government agency is certainly very necessary, as part of the community service, of course the workers employed in local government agencies must be given clear tasks by the leadership of each agency and in carrying out these tasks the leadership must always provide supervision and evaluation. humane to workers with disabilities to reduce errors that may occur. Regarding the relationship between workers, workers with disabilities certainly have limitations in carrying out effective communication. Local government agencies must pay attention to the relationship between workers, both persons with disabilities and non-disabled persons. Harmonious relationships with co- 
workers and without mutual intrigue among co-workers will affect workers with disabilities to survive and increase their morale, in achieving the goals set by their respective local government agencies.

2) The Effect of Communication on Morale:

In the results of hypothesis testing, communication has a positive and significant influence on work morale. The results in this study are in line with the results of research conducted by Luthans (2006:372); Wijaya, et al (2015); Yasa and Wibawa (2015); Widani (2018) which concludes that communication has a positive and significant effect on work morale. This finding implies that the better the communication that exists among the workforce in a Regency/City Local Government Agency in Bali, the higher the morale of workers with disabilities will be.

The test results show that the focus of the higher morale due to communication is openness, empathy, supportiveness and equality (additional). Communication in this case is a two-way process in delivering messages or information by workers with disabilities to other people and vice versa. Workers with disabilities certainly expect an effective communication, especially to fellow co-workers, even though there are limitations in establishing such effective communication. The existence of open communication, namely communication that accepts input from others, and is willing to convey important information to other people is a hope for workers with disabilities. Open communication is the beginning of mutual understanding and there is no mutual cover between workers with disabilities.

Regarding empathy in communication, workers with disabilities expect that someone in their agency can understand and feel something that is experienced by others, can feel what other people feel. Communicating by seeing it from another person's point of view triggers communication that respects each other, so that both workers with disabilities and fellow disabled and non-disabled workers will both understand the shortcomings they have, not give messages or information that offends feelings other people and if this has been established, the morale of the workforce with disabilities will be even higher.

As someone who has limitations, workers with disabilities also expect mutually supportive communication and provide a positive attitude. Communication that supports each other is communication that reflects the attitude between each party who communicates and has a commitment to support the implementation of open interactions. The implementation of this open interaction makes workers with disabilities feel comfortable in carrying out their responsibilities. Communication that provides a positive attitude is an attitude and behavior between parties who communicate to think positively of others, not to be suspicious and believe in the importance of others. This positive attitude in communicating is considered important by workers with disabilities. This indicates that workers with disabilities in communicating put their feelings first. This is inseparable from the limitations that could hinder the establishment of an effective communication process. Workers with disabilities also argue that if someone who is invited to communicate provides an open, supportive, and empathetic attitude, then the communication that exists will lead to mutual trust, mutual respect, not offending other people's feelings, and will make workers with disabilities feel comfort which will then have an impact on increasing work morale.

3) The Influence of Work Motivation on Morale:

In the results of hypothesis testing, work motivation has a positive and significant influence on morale. The results in this study are in line with the results of research conducted by Rozi (2021) which explains that the motivation variable has a positive and significant effect on morale. Sari (2020) also gives results that motivation has a positive effect on employee morale, research with linear results was also found by Iswara and Subudi (2017); Sudiran and Salasiah (2019), and Jaya, et al (2017) who also gave the same results as previous research, that motivation has a positive and significant influence on work morale. This finding implies that the higher the work motivation possessed by workers with disabilities, the morale of workers with disabilities will be higher.

The test results show that the focus of the higher morale due to work motivation is the right work placement. Workers with disabilities consider that the right job placement is important. Due to the limitations they have, disabled workers have not been able to fully 
occupy positions and positions that are usually carried out by workers with disabilities. The local government agency must consider carefully, adjust to the degree of disability with the right position. This suitability also pays attention to the supporting facilities and infrastructure at the agency, so that there is no anxiety for workers with disabilities to reach the given jobs. The right work placement encourages the high work motivation of persons with disabilities at work. If the work motivation of workers with disabilities that occurs in local government agencies is high, it will have an impact on the high morale of workers with disabilities.

4) The Influence of Non-Physical Work Environment on Work Motivation:

In the results of hypothesis testing, non-physical work environment has a positive and significant influence on work motivation. The results in this study are in line with the results of research conducted by Ardiani (2015) showing that the non-physical work environment has a positive and significant influence on work motivation, it is also stated that the variable that has the highest influence on work motivation is the non-physical work environment. Chandra and Viantia (2020) show that the physical and non-physical work environment has a positive and significant influence on work motivation and job satisfaction. This research is also in line with Alisa, et al (2016); Setyadi, et al (2015) and Sinamora, et al (2016) who obtained the results that non-physical work environment variable had a significant simultaneous effect on employee work motivation. This finding implies that the better the non-physical work environment in a local government agency, the higher the work motivation of workers with disabilities.

Motivation is a state in a person's personality that encourages the desire to carry out certain activities in order to achieve a goal. The motivation that exists in a person, will realize a behavior that is directed at the goal of achieving the target of satisfaction. Every activity carried out by a person is driven by a force from within that person; This driving force is called motivation. (Supartha and Sintaasih, 2017:27). The main benefit of motivation is to create work passion / enthusiasm for work. A worker, especially one with a disability, in order to encourage the desire to carry out certain work activities based on their work motivation. In order to create high work motivation, persons with disabilities expect non-physical aspects of the work environment to be considered and run in harmony. Harmony in a good relationship with co-workers, co-workers and with superiors encourages persons with disabilities to have the driving force within them to continue to work with passion and enthusiasm in carrying out their responsibilities.

5) The Influence of Communication on Work Motivation:

In the results of hypothesis testing, communication has a positive and significant influence on work motivation. The results in this study are in line with the results of research conducted by Safitri, et al (2019) which obtained the results that there is a positive influence of communication on work motivation. Similar results were also stated by Yulianto, et al (2014) who concluded that there was a positive contribution between communication and work motivation. As well as research by Soelistya (2014) and Khasanah, et al (2016) which also confirmed the same results, where communication has a significant effect on work motivation, this means that every time there is an increase in communication it will increase employee motivation. This finding implies that the better the communication that exists between workers with disabilities, the work motivation of workers with disabilities will be higher.

Communication must include the transfer and understanding of meaning. Communicating is more than conveying meaning; that meaning must also be understood. Only then can one convey information and ideas (Robbins and Judge, 2017:383). Communication that is established in the agency is certainly considered for workers with disabilities. The existence of good communication, mutual understanding and respect for their limitations makes disabled workers increasingly have high motivation to continue working and hone their abilities in the world of work, especially in local government agencies.

6) The Role of Work Motivation in Mediating the Influence of the Non-Physical Work Environment on Morale:

In the results of hypothesis testing, work motivation is able to partially mediate the influence of the non-physical work environment on morale. The results in this study are in 
line with the results of research conducted by Arifin and Wulandari (2021) which states that the work environment, both physical and non-physical, has a partial effect on the morale of educational staff. Research conducted by Setyadi, et al (2015) gives the result that the nonphysical work environment has a positive and significant effect on work motivation. And research by Pratiwi (2021) also concludes that there is an influence of motivation on work morale, either partially or simultaneously.

Work motivation can also affect employee morale, namely if employees have high work motivation, employee morale will increase (Adnyani and Surya, 2019). Astrohadiwiryo (2008:30) states that high morale is needed in every employee cooperation effort to achieve organizational goals, because high morale will result in high performance and productivity for the company. Therefore, companies need to know in advance what things can motivate and encourage employee morale. This finding implies that work motivation can be a mediating variable, because it has a direct and indirect effect on the work morale variable. The better the non-physical work environment for persons with disabilities in a local government agency, the work motivation of employees will increase so that it will affect the morale of workers with disabilities. Morale:

7) The Role of Work Motivation in Mediating the Influence of Communication on

In the results of hypothesis testing, work motivation is able to partially mediate the effect of communication on morale. The results in this study are in line with the results of research conducted by Khasanah, et al (2016) which proves that communication affects work motivation, it can be concluded that every time there is an increase in communication it will increase employee motivation. Research by Muslih (2020) states that communication that is done consciously or not, will foster a person's motivation so that they tend to be able to change their behavior and activities. Therefore, in terms of one's communication, accuracy, skill and caution are needed so that the motivation formed is in accordance with the expected goals. Jaya, et al (2017) obtained the results that motivation had a positive and significant effect on employee morale. This means that the stronger the work motivation, the higher the employee morale.

So that workers with disabilities can continue to work well within their limitations and provide their best performance for their respective local government agencies, it is necessary to pay attention to their work motivation. The purpose of the company or organization must be to think about how to make employees and employees always passionate about work and have positive behavior in carrying out their duties (Prastowo and Rifai, 2017).

Communication is very important to establish a cooperative relationship between workers who work in local government agencies and has a very large influence in the process of achieving the goals of each agency. Communication will allow each member of the organization to help each other and interact with each other (Simamora and Panjaitan, 2019). This finding implies that work motivation has a direct and indirect influence on the morale variable, which means that the better the communication that exists within an agency, the work motivation of workers with disabilities will increase so that it will affect the morale of the workforce at Regency/City Local Government Agency in Bali.

\section{CONCLUSION AND SUGGESTIONS}

Based on data analysis and discussion in previous chapters, the conclusions of this study are as follows:

1) The non-physical work environment has a positive and significant effect on morale. The results of this study explain that the better the non-physical work environment, the higher the morale of workers with disabilities;

2) Communication has a positive and significant effect on morale. The results of this study explain that the better the communication, the higher the morale of workers with disabilities; 
3) Work motivation has a positive and significant effect on morale. The results of this study explain that the higher the work motivation of the workforce, the higher the morale of workers with disabilities;

4) The non-physical work environment has a positive and significant effect on work motivation. The results of this study explain that the better the non-physical work environment in a local government agency, the higher the work motivation of workers with disabilities;

5) Communication has a positive and significant effect on work motivation. The results of this study explain that the better the communication, the higher the work motivation of workers with disabilities;

6) Work motivation is able to partially mediate the influence of the non-physical work environment on morale. The results of this study explain that the non-physical work environment can directly increase morale. And with a high work motivation, it will be able to increase a greater positive influence on the non-physical work environment on the morale of workers with disabilities;

7) Work motivation is able to partially mediate the effect of communication on morale. The results of this study explain that direct communication can increase morale. And with a high work motivation of the workforce, it will be able to increase a greater positive influence on communication on the morale of workers with disabilities.

Based on the results of research analysis, discussion and conclusions, there are several suggestions that can be used as consideration in determining policies in order to increase the morale of workers with disabilities. The Regency/City Local Government Agency in Bali should focus on the following areas that they believe are currently inadequate and need to be improved:

1) In the non-physical work environment, it is about the clarity of tasks and the reward system received by workers with disabilities. Clarity of duties is a must that is accepted by every worker with disabilities, because it is dominant that people with disabilities are unable to carry out various different tasks such as non-disabled people, then to recognize the work performance of workers, it is recommended that the agency design the program properly;

2) In communication, the thing that needs to be considered is to build a positive attitude in communication. Therefore, communication is important in a team, so it is important to cultivate a positive attitude. Especially for persons with disabilities who in this case have sensitive feelings and intuition, so that this attitude is useful for fostering mutual respect, not being suspicious and a commitment to cooperate even within a limitation;

3) Regarding work motivation, it is deemed necessary to provide comfortable working conditions, recreational facilities and health insurance for workers with disabilities. Comfortable working conditions are expected by workers with disabilities because their limitations require a condition that supports them to work better. Recreational facilities and health insurance are one of the compensations that should be obtained by persons with disabilities as workers. Therefore, it is expected to make policies related to an appropriate and fair compensation system.

\section{REFERENCES}

1. Ali, Ahmad Amer Aafis Mohamed, Daisy Mui Hung Kee, et al. 2020. Does Motivation Improve Employees Job Performance? A Case of Absolute Hotel Services. International Journal Of Tourism \& Hospitality In Asia Pasific, Vol.3, No.3, 9-21.

2. Ali, Bayad Jamal and Govand Anwar. 2021. An Empirical Study of Employees' Motivation and its Influence Job Satisfaction. International journal of Engineering, Business and Management (IJEBM). Vol.5, No.2, 21-30.

3. Alisa, F.A., Musadieq, M.A., dan Mayowan, Y. 2016. Pengaruh Kompensasi Kerja dan Lingkungan Kerja Terhadap Motivasi Kerja (Studi pada Karyawan PT BRI Syariah Kantor Cabang Malang). Jurnal Administrasi Bisnis (JAB), Vol. 32, No. 2. 69-76.

4. Ardana, I. K., Mujiati, N. W. ., \& Utama, I. W. M. 2012. Manajemen Sumber Daya Manusia. Yogyakarta: Graha IImu. 
5. Arifin, Anggi Islamidina, dan Wulandari, Siti Sri. 2021. Pengaruh Tata Ruang Kantor, Lingkungan Kerja dan Prestasi Kerja Terhadap Semangat Kerja Tenaga Kependidikan di SMKS KRIAN 2 Sidoarjo. Jurnal Pendidikan Ekonomi (JUPE), Vol. 9, No. 2, 54-59.

6. Chandra, Daniel Alexander dan Setiawan, Roy. 2018. Pengaruh Lingkungan Kerja dan Iklim Organisasi Terhadap Semangat Kerja Karyawan PT. Diantri. AGORA Vol. 6, No. 1.

7. Chandra, K.L., dan Vianita, S. 2020. Pengaruh Lingkungan Kerja Fisik dan Non Fisik Terhadap Motivasi Kerja dan Kepuasan Kerja Karyawan "Z" Hotel Surabaya. Jurnal Hospitality dan Manajemen Jasa, Vol.8, No.2, 203-219.

8. Danaeefard, Hassan and Abdolali Ahmadzahi Torshab. 2021. Explaining the Mediating Effect of Employee Morale between Organizational Goal Ambiguity and Innovative Work Behaviour: Evidence from the Public Sector of Iran. International Journal Of Public Administration. Vol. 44, No. 13, 1-20.

9. Darmawan, I Gede Widya, dan Wibawa, I Made Artha. 2019. Pengaruh Kompensasi Finansial, Lingkungan Kerja Non Fisik dan Komitmen Organisasional Terhadap Semangat Kerja Karyawan. E-Jurnal Manajemen Unud, Vol. 8, No. 8, 5118-5138.

10. Devi, S and J. Kannadhasan. 2020. A Study On Employee Morale With Special Reference To Neycer India Ltd, Vadalur. Dogo Rangsang Research Journal, Vol.10 No.15, 18-30.

11. Diana, Putu Gidion Alfa dan Subudi, Made. 2013. Pengaruh Komunikasi dan Kompensasi Terhadap Kinerja Karyawan yang Dimediasi oleh Semangat Kerja Karyawan. E-Jurnal Manajemen Unud, Vol. 2, No. 10, 1219-1228

12. Drake, Kirsten. 2021. The moral of morale, Nursing Management (Springhouse). Vol.52, No.3, 56

13. Gautam, D.K. and Basnet, D. 2021. Organizational Culture For Training Transfer: The Mediating Role Of Motivation, International Journal of Organizational Analysis, Vol. 29 No. 3, 769-787.

14. Iswara, I.M.W., dan Subudi, M. 2017. Peran Mediasi Motivasi Kerja dalam Pengaruh Kompensasi Terhadap Semangat Kerja. E-Jurnal Manajemen Unud, Vol. 6, No. 2, 10831111.

15. Jaya, I.G.M.K., Sudibya, I.G.A., dan Sudharma, I.N. 2017. Pengaruh Lingkungan Kerja dan Motivasi serta Kompensasi Terhadap Semangat Kerja Pegawai Dinas Kesehatan Kabupaten Tabanan. E-Jurnal Ekonomi dan Bisnis Universitas Udayana, Vol. 6, No. 2, 533-564.

16. Khasanah, U., Hasionaln, L.B., Warso. 2016. Pengaruh Kepemimpinan, Disiplin Kerja dan Komunikasi Terhadap Motivasi Kerja Karyawan (Studi pada Karyawan Bagian Produksi PT. New March Semarang). Journal Of Management, Vol. 2, No. 2.

17. Kjellstrom, S., Avby, G., et. al. 2017. Work motivation among healthcare professionals: A study of well-functioning primary healthcare centers in Sweden, Journal of Health Organization and Management, Vol. 31 No. 4, 487-502.

18. Kundu, S.C. and Lata, K. 2017. Effects of supportive work environment on employee retention: Mediating role of organizational engagement, International Journal of Organizational Analysis, Vol. 25 No. 4, 703-722.

19. Lee, Y., Tao, W. Li, J.-Y. and Sun, R. 2021. Enhancing Employees' Knowledge Sharing Through Diversity-Oriented Leadership And Strategic Internal Communication During The COVID-19 Outbreak. Journal of Knowledge Management, Vol. 25 No. 6, 1526-1549.

20. Luthans, Fred. 2006. Perilaku Organisasi. Vivin Andika Yuwono, dkk (Penerjemah). Yogyakarta: Penerbit Andi.

21. Mahmoud, A.B., Fuxman, L., et al. 2021. We Aren't Your Reincarnation! Workplace Motivation Across X, Y And Z Generations. International Journal of Manpower, Vol. 42 No. 1, 193-209.

22. Manihuruk, Candra Pranata dan Tirtayasa, Satria. 2020. Pengaruh Stres Kerja, Motivasi Kerja dan Lingkungan Kerja Terhadap Semangat Kerja Pegawai. MANEGGGIO: Jurnal IImiah Magister Manajemen, Vol. 3, No. 2, 296-307. 
23. Minor, K.I., Wells, J.B., et al. 2014. Increasing Morale: Personal And Work Environment Antecedents Of Job Morale Among Staff In Juvenile Corrections. Criminal Justice and Behavior Journals, Vol. 41, No.11, 1308-1326.

24. Murtisaputra, Eko dan Ratnasari, Sri Langgeng. 2018. Pengaruh Lingkungan Kerja, Insentif, Komunikasi dan Senioritas Terhadap Semangat Kerja Karyawan. Dimensi, Vol. 7, No. 3, 434-453.

25. Muslih, Basthoumi. 2020. Urgensi Komunikasi dalam Menumbuhkan Motivasi di Era Pandemi Covid-19. Jurnal Penelitian Manajemen Terapan (PENATARAN), Vol. 5, No. 1, 57-65.

26. Paramina, Patricia Dhiana dan Sari, Heni Susanti Emafika. 2017. Pengaruh Disiplin Kerja, Pengaruh Disiplin, Pengawasan Kerja dan Motivasi Kerja terhadap Kepuasan Kerja Serta Dampaknya Pada Semangat Kerja. (Studi Kasus Pada Karyawan PT. Carefast Semarang). Jurnal Of Management UNPAND, Vol 3, No.3.

27. Pattnaik, Laxmiprada dan Jena, Lalatendu Kesari. 2020. Mindfulness, remote engagement and employee morale: conceptual analysis to address the "new normal". International Journal of Organizational Analysis. Emerald Publishing Limited, Vol. aheadof-print No. ahead-of-print. Vol. 29, No. 4, 873-890.

28. Pekkala, K. 2020. Managing The Communicative Organization: A Qualitative Analysis Of Knowledge-Intensive Companies, Corporate Communications: An International Journal, Vol. 25 No. 3, 551-571.

29. Pratiwi, I Gusti Agung Ayu Inten dan Sariyathi Ni Ketut. 2015. Pengaruh Komunikasi, Motivasi, Dan Penegakan Disiplin Terhadap Kepuasan Kerja Pada Pegawai Dinas Pendapatan Di Kabupaten Tabanan. E-Jurnal Manajemen Unud, Vol. 4, No. 7, 2015, 2176-2191.

30. Prastowo, A.W., dan Rifai, A. 2016. Analisis Motivasi Kerja Karyawan pada PT. Peputra Masterindo Kec. Tapung Kab. Kampar. Jurnal Valuta, Vol. 2, No. 1, 66-82.

31. Rasdam, R., Alam, S., Reni, A. 2018. Analisis Pengaruh Lingkungan Kerja, Kompensasi, Stres Kerja Terhadap Semangat Kerja dan Dampaknya Terhadap Kinerja Karyawan. Hasanuddin Journal of Applied Business and Entrepreneurship, Vol. 1, No. 4, 96-106.

32. Robbins, Stephen P and Judge, Timothy A. 2017. Organizational Behavior. 17th Ed. Pearson Education Limited.

33. Rozi, Fahrul. 2021. Pengaruh Lingkungan Kerja dan Motivasi Terhadap Semangat Kerja Karyawan (Studi Kasus: PT Jaya Anugrah Sukses Abadi pada Brastagi Supermarket Gatot Subroto Medan). Journal Economic and Strategy (JES), Vol. 2, No. 1, 12-20.

34. Safitri, R.A., Risaldi, B.T., dan Oktaviani, M. 2019. Pengaruh Komunikasi Internal Organisasi Terhadap Motivasi Kerja Pegawai Biro Humas Kementerian Perindustrian. Jurnal Riset Komunikasi (JURKOM), Vol. 2, No. 2, 157-170.

35. Sari, Ratna Kartika. 2015. Pengaruh Budaya Kerja 5R dan Komunikasi Internal Terhadap Semangat Kerja dan Kinerja Karyawan. Jurnal Widya Cipta, Vol. 7, No. 2, 141-154.

36. Sari, Yetty Komala. 2020. Pengaruh Motivasi terhadap Semangat Kerja Pegawai pada Kantor Balai Diklat Keuangan Palembang. Jurnal Nasional Manajemen Pemasaran \& SDM, Vol. 1, No. 1, 54-64.

37. Sedarmayanti. 2017. Manajemen Sumber Daya Manusia. Bandung: Refika Aditama.

38. Setyadi, B., Utami, H.N., dan Nurtjahjono, G.E. 2015. Pengaruh Lingkungan Kerja Fisik dan Non Fisik Terhadap Motivasi Kerja dan Kinerja Karyawan (Studi pada Karyawan PT. Bank Bri, Tbk. Cabang Bogor). Jurnal Administrasi Bisnis (JAB), Vol. 21, No. 1.

39. Sharma, Priya. 2021. The Importance Of Team Morale. British Nature, 21-23.

40. Simamora, H.W., Hamid, D., dan Prasetya, A. 2016. Pengaruh Lingkungan Kerja Fisik dan Non Fisik Terhadap Motivasi Kerja Karyawan (Studi pada Karyawan Hotel Atria \& Konferensi Malang). Jurnal Administrasi Bisnis (JAB), Vol. 31, No. 1, 158-166.

41. Simamora, P.R.T., dan Panjaitan, F.M. 2019. Peranan Komunikasi Organisasi dalam Meningkatkan Semangat Kerja Pegawai DPD PDI-P Sumatera Utara. Jurnal Social Opinion, Vol. 4, No. 1, 70-84. 
42. Soelistya, Djoko. 2014. Pengaruh Gaya Kepemimpinan Partisipatif dan Komunikasi Terhadap Motivasi Kerja Serta Dampaknya pada Prestasi Kerja Pegawai di Maspion Group Surabaya Jawa Timur. Jurnal IImu Ekonomi \& Manajemen, Vol. 1, No. 1, 1-10.

43. Sudiran, Fl., dan Salasiah. 2018. Pengaruh Motivasi Kerja Terhadap Semangat Kerja di Bagian Keuangan Dinas Pertanahan dan Penataan Ruang Kabupaten Kutai Timur. EJurnal Administrasi Publik Untag, Vol. 2, No. 3, 1242-1250.

44. Supartha, Wayan Gede dan Desak Ketut Sintaasih. 2017. Pengantar Perilaku Organisasi : Teori, Kasus dan Aplikasi Penelitian.Denpasar Timur: CV Setia Bakti.

45. Supriyati, Darham, Roni, dan Monika. 2020. Pengaruh Kompensasi dan Motivasi Terhadap Semangat Kerja Pegawai pada Puskesmas Teluk Singkawang Kabupaten Tebo. Jurnal Administrasi Sosial dan Humaniora (JASIORA), Vol. 4 No. 1, 103-112.

46. Tambunan, Anggiat Parluhutan. 2018. Lingkungan Kerja dan Kepuasan Kerja Karyawan: Suatu Tinjauan Teoretis. Jurnal IImiah Methonomi, Vol. 4, No. 2, 175-183.

47. Utamajaya, I Dewa Gede Adi Putra dan Sriathi, Anak Agung Ayu. 2015. Pengaruh Motivasi, Komunikasi, Serta Lingkungan Kerja Fisik Terhadap Semangat Kerja Karyawan Pada Fuji Jaya Motor Gianyar. E-Jurnal Manajemen Unud, Vol. 4, No. 6, 1504-1524

48. Wibowo. 2017. Manajemen Kinerja. Edisi Kelima. Depok: PT. Raja Grafindo Persada.

49. Widani, Ni Luh Sri. 2018. Pengaruh Kompensasi dan Komunikasi Terhadap Semangat Kerja Karyawan pada Hotel Puri Dajuma Resort. Jurnal Pendidikan Ekonomi Undiksha, Vol. 10, No. 1, 24-33.

50. Wijaya, Arief Rahman dan Hamid, Djamhur. 2015. Pengaruh Komunikasi Terhadap Semangat Kerja dan Kinerja (Studi pada Karyawan PT. Sumber Cipta Multiniaga Pasuruan). Jurnal Administrasi Bisnis (JAB), Vol. 1, No. 1.

51. Wilson, D.E. 2020. Moving Toward Democratic-Transformational Leadership In Academic Libraries, Library Management, Vol. 41 No. 8, 731-744.

52. Yahyo, Handoyo Djoko W., dan Dewi, R.S. 2013. Pengaruh Motivasi, Lingkungan Kerja, dan Kompensasi Terhadap Kinerja Karyawan Melalui Semangat Kerja Karyawan (Studi Kasus pada Karyawan Bagian Produksi CV. Putra Jaya Sahitaguna, Semarang). Diponegoro Journal Of Social And Politic, Vol.2, No. 2, 1-12.

53. Yani, A., Bake J., dan Sahrun. 2020. Pengaruh Lingkungan Kerja Fisik dan Non Fisik Terhadap Semangat Kerja Karyawan pada PT. PLN (Persero) Area Kabupaten Buton Utara. Business UHO: Jurnal Administrasi Bisnis, Vol. 5, No. 2, 510-521.

54. Yulianto, A.B., Atamadja, N.B., dan Yudana, I.M. 2014. Kontribusi Komunikasi Interpersonal Kepala Sekolah, Budaya Organisasi Dan Etos Kerja Terhadap Motivasi Kerja Guru (Studi Kasus Pada Sekolah - Sekolah Dasar Dibawah Yayasan Menorah Abadi Denpasar). E-Journal Program Pascasarjana Universitas Pendidikan Ganesha, Vol. 5, No. 1. 